\title{
The relationship between maternal characteristics and early childhood caries
}

\author{
Susi ${ }^{1}$, Murniwati $^{1}$, Nila Kasuma ${ }^{2}$, Minarni $^{3}$ \\ 'Department of Dental Public Health, Faculty of Dentistry Andalas University, Indonesia \\ 2Department of Biomedics, Faculty of Dentistry Andalas University, Indonesia \\ ${ }^{3}$ Department of Dental Health, Dental Nursing Study Program, Padang Health Polytechnic, Indonesia
}

\begin{abstract}
Introduction: World Oral Health Organization (WHO) targeted in 2010 that $90 \%$ of children under five years are caries-free. In 2011, the prevalence of Early Childhood Caries (ECC) was 6\%-90\% worldwide. It is still far from the WHO target. Many factors can cause caries; one of them was family characteristics. The objective of the study was to analyse the relationship between maternal characteristics (education, occupation, and the number of children) and early childhood caries. Methods: A cross-sectional study was conducted in the Integrated Post Service (Posyandu) located in the city of Bukittinggi, Indonesia. The sample was 66 parents and their children aged 2-3 years. Maternal characteristic was obtained by interview, whereas the ECC was measured using the def-t index. Data were collected and analysed by the Chi-square test. Three dentists and two dentistry students collected the calibrated data. Results: ECC prevalence was 50\% (Cl 95\%; 38\%-62\%) with the def-t index of $2.23 \pm 2.81$ ( $\mathrm{Cl}$ 95\%; 1.53-2.92) and caries significant index (CSI) was 5.73. The prevalence of caries-free was found highest in children with working mothers $(66.7 \%)$ and the lowest (31.6\%) in children with basic educated mothers. The highest def-t index was $3.17 \pm 3.212$, which was found in three-years-old children, and the lowest was $1.98 \pm 2.915$, which was found in children with advance educated mothers. Conclusion: There was no relationship between maternal education level, occupation, and the number of children with early childhood caries.
\end{abstract}

Keywords: Early childhood caries, def-t, mothers characteristic, prevalence, Caries Significant Index.

p-ISSN: 1979-0201; e-ISSN: 2549-6212; Available from: http://jurnal.unpad.ac.id/pjd/article/view/23640

DOI: 10.24198/pjd.vol32no1.23640

Submission: Sep 16, 2019; Accepted: Mar 17, 2020; Published online: Mar 31, 2020

\section{INTRODUCTION}

Early childhood caries (ECC) is caries occurring in the deciduous teeth of children under the age of 71 months. ${ }^{1} \mathrm{ECC}$ is the most common infectious disease and significant health problem children worldwide, and its prevalence is increasing in several countries. The prevalence of ECC is $6-90 \%{ }^{2}$

The prevalence of ECC in the United States is five times higher than asthma and seven times

"Corresponding author: Susi, Department of Dental Public Health, Faculty of Dentistry Andalas University, Jalan Perintis Kemerdekaan No. 77, Padang, West Sumatera, Indonesia, 25171. Phone: +628126752834; Email: susi@dent.unand.ac.id 
higher than rhinitis. ${ }^{3,4}$ The prevalence of ECC in Central Trinidad was $29.1 \%$ for children aged 3-5 years. ${ }^{5}$ Prevalence ECC in Bukittinggi Indonesia, $51.5 \%$ for children two to three years old. ${ }^{6}$ Caries of deciduous teeth gets only few attention from parents. Most of the parents think that temporary teeth, the permanent teeth, will be replaced deciduous teeth. ${ }^{7}$

Caries will disrupt the function of mastication and daily activities because children cannot eat and drink. ${ }^{8}$ Lack of food intake will affect the growth and development of children. Caries also causes aesthetic disorders in children so that they have low self-esteem and affect the children's quality of life. ${ }^{7,8}$

Caries is a disease caused by multifactorial. Host, bacteria, substrate, and time are the etiological factors. Risk factors influenced caries, including demographic characteristics, oral hygiene, parental education, socioeconomic status, oral habits, number of children. Family characteristics are one of the elements factors that caused caries. Parents are responsible for the health of their family members, including their children. Parents who have sufficient knowledge of oral hygiene will influence their behaviour in maintaining the health of their children. ${ }^{5,9}$

Caries is an infectious disease that can be prevented, and prevention started in children. ${ }^{10}$ Knowing the prevalence and factors associated with caries is useful to determine the interventions to be carried out to prevent and develop caries. Maintenance of dental health in preschoolers depends on their parents, especially mothers, as the closest person to the children. Jobs are categorised into working and jobless. The level of education is categorised as basic if the highest education in middle school and advance if the level of education is at least high school. This study was aimed to analyse the relationship between maternal characteristics (education, occupation, and the number of children) and early childhood caries.

\section{METHODS}

This research was a crossectional study located in integrated post service (Posyandu) Bukittinggi. The sample is taken from all the districts in Bukittinggi (Aur Birugo Tigo Baleh, Guguk Panjang dan Mandiangin Kota Selayan). Permission for the research obtained from Research Ethics no. 065/KEP/FK/2017 Faculty of Medicine, Andalas University, Padang West Sumatera.

The number of samples was determined based on the WHO manual determines the sample size. ${ }^{11}$ The subjects chosen by purposive sampling technique of 66 mothers and children aged two to three years with four upper anterior teeth have erupted. This age was chosen because it is almost all primary teeth have erupted, and child dental care is very dependent on their parents. ${ }^{9}$ one family represented by one child at a very young age. Data was taken by three dentists and two students from the Faculty of Dentistry Andalas University. They have been calibrated beforehand with an intra-examiner and inter-examiner with a conformity value $\geq 0.8$. The data collected under the supervision of the head of the researcher.

Data is taken from July to November 2017 in Bukittinggi. The children are categorizing into less and more than two. Early childhood caries assessed by clinical examination using the deft index. During the examination, the children accompanying his mother. Mouth mirrors and probes used if needed. Early childhood caries categorized by the American Academy of Pediatric Dentistry (AAPDC) if one or more caries were present. ${ }^{1}$ (AAPD) Data is analyzed using the Statistical Package for Social Science (SPSS). Significant if $p<0.05$ (Significance level 95\%). The caries prevalence between 2 groups was analyzed using the chi-square test.

\section{RESULTS}

A total sample of 66 children consisting of 25 males (37.8\%) and 41 females (62\%) in Bukittinggi aged 24 months to 36 months with an average age of 30 months. ECC prevalence is $50 \%$ ( $95 \%$ confidence interval 38\%-62\%). The deft index of $2.23 \pm 2.81$ $\mathrm{SD}(95 \% \mathrm{Cl} 1.53-2.92)$. Caries significant index (CSI) 5.73. The prevalence of ECC is highest in children age 36 months $(66.7 \%)$ and the lowest in children with working mothers (33.3\%). The highest deft index 3.17 \pm 3.212 SD in children three years old and the lowest $1.98 \pm 2.915$ in children with advanced educated mothers. (table 1).

Children with caries-free was highest in children with working mothers (66.7\%) and lowest in children with primary education mother $31.6 \%$. 
Table 1. Prevalence of early childhood caries (ECC) and deft index

\begin{tabular}{lcccc}
\hline Variable & $\mathrm{n}$ & ECC prevalence & x deft & SD \\
\hline Gender & 25 & $13(52.0 \%)$ & 2.56 & 3.137 \\
Male & 41 & $20(48.8 \%)$ & 2.02 & 2.622 \\
Female & & & & \\
\hline Age & 24 & $16(66.7 \%)$ & 3.17 & 3.212 \\
Three years old & 42 & $17(40.5 \%)$ & 1.69 & 2.444 \\
Two years old & & & & \\
\hline Mother's occupation & 21 & $7(33.3 \%)$ & 2.19 & 3.628 \\
Employed & 44 & $26(57.8 \%)$ & 2.24 & 2.395 \\
Unemployed & & & & \\
\hline Education level & 19 & $13(68.4 \%)$ & 2.84 & 2.525 \\
Basic & $20(42.6 \%)$ & 1.98 & 2.915 \\
Advance & 47 & $14(53.8 \%)$ & 2.04 & 2.254 \\
\hline Number of children & & $19(47.5 \%)$ & 2.35 & 3.150 \\
$>2$ & 26 & & & \\
$\leq 2$ & 40 & & & \\
\hline
\end{tabular}

Table 2. Maternal characteristic and ECC

\begin{tabular}{lccccc}
\hline \multirow{2}{*}{ Maternal characteristic } & \multicolumn{2}{c}{ ECC } & \multicolumn{2}{c}{ No ECC } & P-value \\
\cline { 2 - 6 } & $\mathrm{N}$ & $\%$ & $\mathrm{~N}$ & $\%$ & \\
\hline Employed & 7 & 33.3 & 14 & 66.7 & 0.113 \\
Yes & 26 & 57.8 & 19 & 42.2 & \\
No & & & & & \\
\hline Education & 13 & 68.4 & 6 & 31.6 & 0.103 \\
Basic & 20 & 42.6 & 27 & 57.4 & \\
Advance & & & & & \\
\hline Number of children & 14 & 53.8 & 12 & 46.2 & 0.801 \\
$>2$ children & 19 & 47.5 & 21 & 52.5 & \\
$\leq 2$ children & & & & & \\
\hline
\end{tabular}

There is no significant relationship between maternal characteristics and ECC (Table 2).

\section{DISCUSSION}

A sample of 66 pairs of children and mothers (one child for every parent) with an average age of 30 months consisted of 41 (62\%) girls and 25 (38\%) boys. The prevalence of ECC is 50\% (95\% confidence interval $38 \%-62 \%)$. Deciduous teeth begin to erupt at six months and complete eruption at 24 months. Increasing age can increase the risk for caries because the teeth exposed to longer risk factors 4 .

The interaction of these factors makes imbalance demineralization and remineralization. Bacteria in plaque will ferment carbohydrates into acid. The acid will dissolve the calcium phosphate in enamel and dentin, causing the cavity to occur. Increasing age increases the risk of caries. The deciduous teeth are more susceptible to caries because the enamel structure is less dense and thinner than permanent teeth. ${ }^{12}$

In this study, the prevalence of caries at the age of 2 years was $40.5 \%$, whereas, at the age of 3 years, the prevalence increased to $66.7 \%$. The prevalence of caries in this study still far from WHO / FDI target in 2020, which is $68 \%$ of children under 12 years of age free of caries..$^{13}(\mathrm{FDI})$ The results of this study are almost the same as the prevalence of ECC in children under three years old in Jakarta at $52.7 \%$ in $2007 .{ }^{14} \mathrm{At}$ the age of two to three years, the child's motor development is stimulated by imitating activities. The child will emulate the behaviour of people in his environment. 
The average of the deft index is $2.23 \pm 2.81$ SD (95\% Cl 1.53-2.92). The index of this research range from 0 to 10 . The average sample has caries between two to three teeth. This figure is still far from the target of the Indonesian Ministry of Health in 2030, children under 12 years of age free from caries. The results of this study are lower than the deft index for children under the age of three years in Jakarta 2.85 and lower the results of research for children aged three to five years in Ughur with a deft index of $3.95 .{ }^{14,15} \mathrm{Caries}$ significant index (CSI) 5.73 , showing one-third of the sample (22 children) with the highest caries has average caries in this study of more than five teeth. The results showed that six samples had a deft index of 5 . High CSI requires more treatment in the future. ${ }^{16}$ (Douglas) In 2020 WHO / FDI targets a CSI value of $\leq 3$ to achieve Health for all. ${ }^{13}$

The prevalence of caries boys and girls is almost equal (52.0\% vs. $48.8 \%)$. Girl's teeth erupt faster than boy's teeth. Girls' teeth are exposed to bacteria longer in the oral cavity and are more at risk for caries. Results of research in Tamil Nadu for 18-72 month-old children, the prevalence of male caries is higher than women. ${ }^{17}$ The results of research in India stated the prevalence of caries in toddlers girls is higher than in boys. ${ }^{15} \mathrm{Gender}$ at this age does not affect the occurrence of caries, because, at this age, children are very dependent on parenting.

Children with working mothers have a lower average of a deft index than those who don't work. Statistical test results showed no significant relationship between children and mothers who work with ECC. The results of this study are in line with research in Padang concerning the work of mothers with caries in toddlers aged five years. ${ }^{18}$ Working mothers in this study are mothers who work and leave home. Nowadays, the opportunity for women to work outside the house is higher. The working mother environment was more comfortable getting information about health. Working mothers will leave their children with trustworthy caregivers, like family or professional staff. The caregiver will treat the child's teeth according to instructions from the working mother so that the child's dental health status is maintained. Mothers who do not work have more time to look after and care for their children's health. ${ }^{19,20}$ Mothers who did not work in this study actively participated in Posyandu activities. Posyandu is a means of community empowerment that aims to monitor the growth and development of children under the age of five.

This study showed that the prevalence of ECC is lower in children with higher-educated mothers, while the prevalence of ECC is higher in children with low-educated mothers. The result of the statistical test shows that there is no significant correlation between education level and ECC. The basic education level is using as an indicator of the level of education by the Ministry of Education program for nine years off compulsory schooling. Research study in Indonesia $79.34 \%$ woman with level education junior high school. ${ }^{21}$ In this study, $71 \%$ of the mother had advanced education levels. A mother's level of education will affect her knowledge, attitudes, and actions. Mothers with proper levels of education will quickly find, understand, and analyze the information received. The results of Kerrod B.H \& K.O'Rouke's research in 2006 stated that maternal education has a significant relationship with the severity of ECC. ${ }^{22}$ Knowledge, beliefs, and attitudes of parents will affect the mothers' behaviour in maintaining child's dental hygiene. ${ }^{15}$

Children with more than two siblings have a higher average of deft index compare to children with less than two siblings. Parents often prioritize the needs of the first child and strive to fulfill all the wishes of the child, including the habit of snacking and the consumption of cariogenic foods. The number of children in the family does not have a meaningful relationship with the ECC. The number of children in the family will affect the economic needs of the family. A family with many members, the child, will share the attention of both parents with the siblings. Families with fewer family members will be more comfortable in fulfilling the economic needs of the family. $18,19,20$

The mother dominates the Indonesian relationship families as the primary caregiver. The link is very close to mother nurturing, feeding and drinking with the same spoon, sleep together, and others facilitate the transmission of S.Mutans bacteria. Mothers with higher caries experience, poor oral hygiene, socioeconomic, and low education are at high risk for S. mutants in their children. The results of the study showed that there is transmission of S. mutants from mother to child. ${ }^{23}$ 
A limitation of the study was that the dental examinations of the respondents were carried out visually using a mouth glass if needed because some children refused to use it. Data collection takes a long time because activities at Posyandu are once a month. Further research is recommended to be carried out in PAUD, which has activities every working day.

\section{CONCLUSION}

There is no significant relationship between maternal characteristics (occupation, education level, and number of children with Early Childhood Caries (ECC).

\section{REFERENCES}

1. American Academy of Pediatric Dentistry. Policy on early childhood caries (ECC) classification, consequences, and preventive strategies. Pediatr Dent 2014;37:50-52.

2. O'Mullane D, Parnell C. Early childhood caries: A complex problem requiring a complex solution. Community Dent Health 2011;28(4):254. DOI: 10.1922/CDH_1211EdOMulllane01.

3. Pierce KM, Rozier RG, Vann WF. Accuracy of pediatric primary care providers. Screening and referral for early childhood caries. Pediatrics. 2002;109(5):E82-2. DOI: 10.1542/ peds.109.5.e82.

4. Hale KJ, American Academy of Pediatrics Section on Pediatric Dentistry. Oral health risk assessment timing and establishment of the dental home. Pediatrics. 2003;111(5 Pt 1):1113-6. DOI: $10.1542 /$ peds.111.5.1113.

5. Naidu R, Nunn J, Kelly A. Socio-behavioural factors and early childhood caries; a crosssectional study of preschool children in central Trinidad. BMC Oral Health 2013;13:30. DOI: 10.1186/1472-6831-13-30.

6. Susi S, Murniwati M, Kasuma N, Minarni M. Analysis of Breastfeeding Pattern with Early Childhood Caries. World J Dent 2018;9(3):197200. DOI: $10.5005 /$ jp-journals-10015-1533.

7. Acharya S, Tandon S, The effect of early childhood caries on quality of life children and their parents. Contemp Clin Dent. 2011 Apr-Jun;2(2):98-101. DOI: 10.4103/0976237X.83069.
8. Low W, Tan S, Schwartz S. The effect of severe caries on the quality of life of young children. Pediatr Dent 1999;21:325-6.

9. Alhabdan YA, Albers AG, Yenugadhati N, Jradi $\mathrm{H}$. Prevalence of dental caries associated factors among primary school children: a population-based cross-sectional study in Riyadh, Saudi Arabia. Environ Health Prev Med. 2018;23:60. DOI: 10.1186/s12199-0180750-z.

10. Krol DM. Educating pediatricians on children.s oral health: past, present, and future. Pediatrics. 2004;5:e487-933. DOI: $10.1542 /$ peds.113.5.e487.

11. World Health Organization. Sample size determination in health studies: A practical manual / SK. Lwanga and S. Lemeshow. 1991: 23-36.

12. Kidd EA, Fejerskov O. What Constitutes Dental Caries? Histopathology of carious enamel and dentin related tooth action of cariogenic biofilms. J Dent Res 2004;83:C35-38.

13. Hobdell M, Petersen PE, Clarkson J, Jonson N. Global Goals for Oral Health 2020. Inter Dent J 2003;53:285-8.

14. Sugito FS, Djoharnas H, Darwita RR. Breastfeeding and early childhood caries (ECC) severity of children under three years old in DKI Jakarta. Makara Kesehatan December 2008;12(2):86-91.

15. Wulaerhan J, Abudureyimu A, Bao XL, Zhao J. Risk determinants associated with early childhood caries in Ughur children: a preschoolbased cross-sectional study. BMC Oral Health. 2014 Nov 18;14:136. DOI: 10.1186/1472-683114-136.

16. Bratthal D. Introducing the significant caries index together with a proposal for a new global oral health goal for 12-year-olds. Int Dent J. 2011;50(6):378-84. DOI: 10.1111/j.1875595X.2000.tb00572.X.

17. Stephen A, Krishnan R, Ramesh M, Kumar VS. Prevalence of early childhood caries and its risk factors in 18-72 month old children in Salem, Tamil Nadu. J Int Soc Prev Community Dent. 2015 Mar-Apr;5(2):95-102. DOI:10.4103/22310762.155731.

18. Susi, Bachtiar H, Azmi U. Hubungan status social ekonomi orang tua dengan karies gigi sulung anak umur 4 dan 5 tahun. Maj 
Kedokteran Andalas 2012:1(36):96-105. DOI: 10.22338/mka.v36.i1.p96-105.2012.

19. Putri RF, Sulastri D, Yuniar L. Faktor-faktor yang berhubungan dengan status gizi anak balita di wilayah kerja Puskesmas Nanggalo Padang. Jurnal Kesehatan Andalas 2015:4(1):254-261. DOI: $10.25077 / j k a . v 4 i 1.231$.

20. Hamal DK. Hubungan pendidikan dan pekerjaan orangtua serta pola asuh dengan status gizi balita di kota dan Kabupaten Tangerang Banten. Jurnal Penelitian Gizi dan Makanan. 2011;26(2):10-9.
21. Kementrian Pemberdayaan Perempuan dan Badan Pusat Statistik. Profil Perempuan Indonesia 2018. p. 16.

22. Kerrod B Hallett, Peter K'Rourke. Early childhood caries and infant feeding practice. Community dental health. 2002;19(4):237-42.

23. Ramos-Gomez FJ, Weinstraub JA, Gansky $\mathrm{SA}$, Hoover $\mathrm{Cl}$, Featherstone JD. Bacterial, behavioural, and environmental factors associated with early childhood caries. J Clin Pediatr Dent. 2002 Winter;26(2):165-73. DOI: 10.17796/jcpd.26.2.t6601j3618675326. 